\title{
17. The Kastom System of Dispute Resolution in Vanuatu
}

\author{
Miranda Forsyth
}

This paper is a short report of the progress of my doctoral research into the indigenous, non-state system of dispute management in Vanuatu, which is called the kastom system for the purposes of the study. This paper will discuss the research questions the study is based on, the operation of the kastom system generally, two of the leading principles of the kastom system, the challenges facing the kastom system today, the relationship of the kastom system with the state system and finally the problems with that relationship. ${ }^{1}$

\section{Research questions}

The central issue with which the study is concerned is determining what the relationship between the kastom system and the state system is, and how it can be improved. In addressing this issue there are a number of sub-questions which must be asked: How is the kastom system currently operating in Vanuatu? What is perceived by the stakeholders as being the current relationship between the kastom system and the State justice system? What do the stakeholders consider to be the current problems with the relationship between these two systems and what reasons do they suggest are the cause of these problems? Do the stakeholders think the two systems should remain working in their current relationship or might another form of relationship better meet the needs of the people of Vanuatu? What model or models of a relationship between the two systems would allow the two systems to better meet the needs identified by the stakeholders?

\section{Research methodology}

The methodology which was used to conduct the study utilised a variety of approaches, many of which involved collaboration with the Vanuatu Kaljoral Senta (VKS). The principal methodology was in-depth interviews with key actors in both systems, and these were conducted throughout Vanuatu. In addition,

1 Subsequent to this paper being presented, the doctoral research has been completed and published as a book (Forsyth 2009). 
to overcome the problem of my inability to attend actual kastomkot meetings, the VKS fieldworkers assisted me in filling out 'KastomKot Observation Forms' to provide information about the actual cases which were dealt with in their communities. Over the course of two years, twenty of these completed forms were returned to me and were very useful in giving examples of matters decided and the types of procedures which were followed. The VKS's Young People's Project (YPP) was another focus of collaboration which involved a list of my questions being attached to a general questionnaire the YPP was administering throughout Vanuatu. Two additional methods of finding out information came from my experience of working in the Vanuatu Public Prosecutor's Office for a year and also through the holding of the Vanuatu Judiciary Conference 2006 which had as its focus the relationship between the two systems, and which brought together chiefs, police, lawyers and the judiciary to discuss a number of the issues involved with their co-existence (Forsyth 2006).

\section{The operation of the kastom system}

The kastom system in one form or another exists in every village and town in Vanuatu. It is indisputably the place where the vast majority of disputes in every rural and urban community in the country are dealt with. The central idea of the kastom system is that the chief or chiefs of a community are responsible for managing disputes and they do so through holding a public meeting with the parties involved at which the dispute is discussed, responsibility allocated and amends made through the payment of a custom fine by one or both of the parties. This fine is generally in the form of pigs, mats, kava, food and increasingly cash. Around this base there is a large diversity in the means of resolving disputes throughout the archipelago. For example, one respondent describes the process in Ambae:

Once the parties have put their cases and [their points of] view the meeting breaks off after having elected some judges. These judges are not formally nominated; it is just known which people have the most knowledge and wisdom and have been fair in the past. These people then go away and discuss between themselves what to do and then return and announce how the reconciliation is to be reached. The parties are then called to comment on the decision and if there is disagreement then the meeting will not end until agreement is reached. The contribution of both parties is significant in coming to a reconciliation.

In contrast, in North Pentecost the process was said to be as follows:

When there is a meeting everyone gathers in the nakamal and the chairperson of the village council tells the chiefs that they will be 
responsible for making a decision. The chairperson directs the meeting. $\mathrm{He}$ is chosen by the village but is not necessarily a chief. Everybody talks, to give evidence and so on. At the end of the talking everyone goes outside and leaves the chiefs to discuss the issue and come to a decision. Then they come back inside and the chiefs say what their decision is. Then everyone goes back to their houses to look for pigs and red mats... There is never any negotiation about the fine.

The matters that the kastom system in each area deals with depends on a number of factors, including the beliefs of the chiefs as to what cases they can manage to deal with, community support, and the accessibility of the state system. Thus in some places it only deals with minor disputes, whereas in other places it deals with everything, including murder.

\section{Guiding principles of the kastom system}

\section{Restorative principles}

The basic principles of the kastom system as enunciated by the chiefs and as practiced in the vast majority of cases are restorative, in that the focus is on restoring relationships that have been broken by the dispute. Two of the main stated aims of any kastom meeting are: 'blong mekem [tufala pati] shake han mo kam gudfala fren bakegen' [to make the two parties shake hands and become good friends again] and to allow the defendant to 'mekem gud fes' (literally 'clean [the person's] face', meaning to get respect in the community again). The purpose of this second aim is so that the defendant can once again become a functioning member of the community and any avoidance that may have been practised before the meeting can cease, which is important in small and interdependent communities.

The kastom process generally takes a holistic approach to the disputes, taking into account a wide variety of matters including the underlying causes of the conflict. It is for this reason that the payment of goods and cash are often in both directions, rather than having a single winner and a single loser as in the state system. For example, a chief gave an example of the holistic approach taken in kastom:

In kastom if John comes and looks at Brown and Brown swears at him, John fights him. In court if a man says that he fought the man then he is punished but the one who swore does not get any punishment. So John goes and fights him again. The way that the ni-Vanuatu look at it is to ask who started the dispute and to punish that person as well. 
This approach also means that sometimes even people other than the parties are fined. This is illustrated by a case about 'jealousy' which occurred in Ambae. A man suspected that his wife, a nurse, was having an affair with $\mathrm{Z}$, one of her co-workers. Initially a village court heard the case and it was settled, but then $Y$ started to talk to the jealous husband, stirring him up and suggesting that his wife and $\mathrm{Z}$ had been lying. The case then was taken up again at the area level where the chiefs 'found' that although the wife had not had an affair with $\mathrm{Z}$ she had provoked the jealousy because she had once telephoned him when she was away and had told him she was calling from a different place than the place she actually was. The end result was that the wife was ordered to pay a fine, but the heaviest fine was imposed on $\mathrm{Y}$ who had to pay a fine to the chief, to $\mathrm{Z}$ and to the husband for the trouble he had caused.

Importantly, at times the restorative principles are not always followed and the kastom system is used as a means of punitive control. An example of this is given by a respondent who stated:

I will tell you about a case of a relative of mine. She had 'flatem' [finished] all the men around her and made lots of women very angry with her. The chiefs tried everything they could to stop her-they cut off her hair, and they all whipped her. Then finally they sent her back to the island. She stayed there for ten years and she saw how hard life was there, not like getting paid money for sex, and now she has come back to Vila ten years later a changed woman. Now she stands next to the chiefs to assault the women who have children with no fathers!

\section{Peace and harmony in the community}

Another central principle of the kastom system is that of restoring peace and harmony to the community. At times this principle conflicts with the restorative notions of the kastom system; for example victims who may not really be happy with the decision are forced to accept it and 'shake hands' for the good of the community. This principle may also conflict with notions of individual rights as the peace of the community is prioritised over individual justice.

\section{Challenges for the kastom system today}

There are significant challenges facing the operation of the kastom system today. The major problem with the kastom system today from the point of view of the chiefs is that many chiefs find it difficult to effectively wield authority, as people refuse to listen to their orders, to come to meetings and to pay the fines levied upon them. The reasons for this are partly created by the chiefs themselves 
(disputes over chiefly title, biased decision-making and chiefs acting contrary to their own kastom laws lessen peoples respect for them); partly a result of the increasing westernisation of society (increasing emphasis on individual rights and a materialistic approach to life lessens the force of community ties and respect); and partly a result of the existence of the state system (community members challenge the chiefs on the basis that they have no authority under the Constitution, the police prevent them from using force to enforce their orders and people take disputes to the state system if they are not satisfied with the chiefs' decision thus undermining their authority).

The main problems identified by non-chiefs with the system are: in many places the kastom system discriminates against women and youth, both procedurally by denying them a voice and also substantively, for example by fining a woman more than a man in a case of adultery; the widespread perception of bias among the chiefs, and even more problematically, the fact that there is no real way of dealing with biased, unfair, lazy or incompetent chiefs. As a result, many communities face the problem of believing in the kastom system and its advantages in principle, but not being able to access them because of their particular chief.

One positive finding is that despite these problems, the kastom system today is generally well-supported by the whole population, including women and youth, for its many benefits, including its essentially restorative nature, its accessibility; its familiarity; its ability to bring about peace and the fact that it is 'their' system.

\section{The relationship with the state system}

The kastom system itself is not legally recognised by the state, although the Constitution does recognise substantive customary law as a source of law. Elements of the kastom system are also recognised in a few minor ways by the state system, such as in provisions in the Criminal Procedure Code which allow the court to take customary settlements into account while sentencing. Essentially, however, at present the two systems operate very much in parallel rather than together, and their points of intersection are fluid and subject to negotiation by the individuals involved.

Each of the different state agencies (police, courts, prosecutors etc.) has an informal and dynamic relationship with the state system, which varies from place to place and from time to time. For example, in some areas the police require people to put the disputes before the chiefs before they lodge a complaint, whereas in others there is no such requirement. 
The approach of the state towards the chiefly system has essentially been to rely upon it to maintain law and order where the state resources cannot reach, or are not accepted, but to deny any requests from the chiefs for state power to assist them in carrying out their duties, claiming that the source of the chiefs' power should be kastom and respect rather than state power. It is argued that this approach fails to take into account the fact that it is largely the presence of the state system itself which undermines the chiefly system, and that the kastom system cannot rely on the strength of respect alone to keep functioning in the changing circumstances of Vanuatu today.

\section{The problems of the relationship between the state system and the kastom system}

Whilst there are many benefits to having a degree of flexibility in the relationship, especially in light of the enormous variation in circumstances throughout the country, the unregulated nature of the relationship also generates many problems.

A fairly typical scenario demonstrates some of the major problems in the relationship:

Jane is raped by her step-brother John. The chiefs of Jane's community call a meeting and John is fined. Two months pass and John has not paid his fine. Jane asks the chiefs what to do and the chiefs say they have no power to force John to pay. Jane goes to the police and makes a complaint. The police investigate but find it difficult as much evidence has been lost and the witnesses have become compromised. A file is prepared and it goes to court. John then comes to the chiefs and says he is willing to pay his fine if the case is withdrawn and so Jane is pressured by her family to withdraw the case. Jane goes to withdraw the case and the police and prosecution get angry with her and accuse her of wasting their time. John does not pay the fine. The police will not accept another complaint from Jane. ${ }^{2}$

The problems shown in this case study are just a few examples of the problems which exist. Although the nature of the problems varies throughout Vanuatu, the following are the most common. The uncertainty about where the dispute should be dealt with puts complainants in a vulnerable situation (this is shown by the example of Jane above). There is considerable dispute and confusion about which system should hear which types of cases (even in areas where there is an informal policy that the chiefs decide 'minor' cases and the state decides

2 This is not an actual case study, but is a simplified imagined one based on a number of actual cases. 
'serious' cases there are arguments because of different views of what constitutes each type of case). There is an unresolved problem of which system should deal with a case first (this is problematic when a case goes to both systems and for example the chiefs want to hold a reconciliation ceremony before the defendant makes a plea). The problem of 'double jeopardy' (often defendants feel they have been 'doubly punished' if they are sentenced in the court as well as in kastom). The operation of the state system creates feelings of disempowerment on the part of chiefs and also frustration as they are told to be responsible for their communities but hindered by the state system in carrying out their duties in the following ways:

- sometimes courts make orders that interfere with chiefs' ability to do their work (for example, bail conditions, protection orders);

- sometimes the state prosecutes chiefs for making various orders (for example, the case of Public Prosecutor v Kota);

- sometimes courts make different orders to those the chiefs have made, which again undermines the chiefs' authority and respect in the eyes of the community;

- the ability to 'appeal' to the state system undermines the enforcement power of the chiefs; People challenge the chiefs on the basis that what they do is not in the Constitution;

- the existence of the kastom system also hinders the operation of the state system; cases are often withdrawn from the system after they have been 'dealt with' in kastom, creating feelings of frustration for prosecutors and police who have worked on the cases;

- people see the state system as 'foreign' in comparison: this is demonstrated by the courts are often being called 'kot blong waetman';

- people can de-legitimise decisions made by the state by saying the kastom system would decide differently

\section{Conclusion}

This short paper has shown many of the challenges and possibilities of the plural legal order in Vanuatu. The work that lies ahead is to identify some changes which can be made to both the state and the kastom systems to allow them to work better together, in a way which supports, rather than undermines, each other. 
Working Together in Vanuatu

\section{References}

Forsyth, Miranda, 2006. Report On The Vanuatu Judiciary Conference 2006: The Relationship Between The Kastom and State Justice Systems. Online: http:// www.vanuatu.usp.ac.fj/sol_adobe_documents/usp \%20only/pacific \% 20 law/forsyth3.htm, accessed 11 May 2011.

Forsyth, Miranda, 2009. A Bird that Flies with Two Wings: Kastom and State Justice Systems in Vanuatu. Canberra: ANU ePress. 